\section{Commodification of children again and non-disclosure preimplantation genetic diagnosis for Huntington's disease}

\section{Spriggs}

\section{When is commodification acceptable?}

$\mathrm{P}$ reimplantation genetic diagnosis (PGD) is usually restricted to couples who are eligible for in vitro fertilisation (IVF)-infertile couples or those with a history of genetic disease. The Human Fertilisation and Embryology Authority (HFEA) in England and the Infertility Treatment Authority (ITA) in Australia have both given permission for PGD with tissue typing to detect human leucocyte antigen (HLA) compatibility in order to save an existing sibling with a life threatening condition. The procedure has also been carried out in the United States. ${ }^{1}$

Heavy criticism followed the February 2002 ruling of England's HFEA to allow a family to try for a child who is free of thalassaemia and a "perfect match" for a sick sibling. ${ }^{2}$ Then in August 2002, the HFEA refused an application for the procedure to be used by the parents of a child suffering from Diamond Blackfan Anaemia. The application was refused because there is no genetic test for Diamond Blackfan Anaemia. The HFEA will only allow a cell to be tissue typed if it has already been taken to test for illness-and where there is no genetic test there is no reason to take a cell. ${ }^{3}$ (The parents of the child suffering from Diamond Blackfan Anaemia travelled to

Abbreviations: CCNE, National Consultative Ethics Committee for Health and Life Sciences; HFEA, Human Fertilisation and Embryology Authority; HLA, human leucocyte antigen; ITA, Infertility Treatment Authority; IVF, in vitro fertilisation; PGD, preimplantation genetic diagnosis the United States where they were able to genetically select an embryo to match the tissue of their existing child. ${ }^{4}$ )

Critics of PGD and tissue typing worry that babies will be created to harvest "spare parts" and will not be valued in their own right. Creating a child in the interests of a third party is troubling, they argue. According to Dr Anthony Cole, chairman of the Medical Ethics Alliance: "All children are of inestimable value in themselves and it is contrary to their dignity, and the dignity of their procreation, to be selected, conceived, and utilised for the benefit of another". ${ }^{5}$ The help given "must be ethically acceptable" argues Josephine Quintavalle, spokesperson for a group called Comment on Reproductive Ethics. ${ }^{6}$

The interests and dignity of the child has also figured prominently in France's National Consultative Ethics Committee for Health and Life Sciences (CCNE) in relation to another new extension of PGD. In 2001, two applications of PGD in the interest of a third party were referred to the committee for consideration. One application concerned PGD to detect HLA compatibility for families affected by Fanconi's anaemia and the second application, the new extension of PGD, involved a couple's request for PGD to screen out Huntington's disease without being informed of their own genetic status. PGD is required in this situation because one of the parents comes from a family affected by Huntington's disease and does not wish to know their status. In giving its opinion, in its July 2002 report, the CCNE said it wanted to "draw attention to the serious and major issues" that decisions of this kind generate. ${ }^{7}$

According to the CCNE, the PGD with non-disclosure situation is "significantly different" from the other kind of situation in which PGD is a "remedy" for a sick sibling. With creating a child to save a sibling the "essential problem" is the "authenticity of the parental project" and the "risk of a child becoming a commodity".

The committee concluded that: "A child's own interest must never be obscured by the interest of another". With regard to the non-disclosure situation, the committee identified issues such as cost, eliminating unaffected embryos, children's rights, and the right to bear children but declared: "there is no doubt that the parents actually want a child and that this is their main concern. So the interest of the future child is protected ...". ${ }^{7}$

J Med Ethics 2004;30:538.

doi: 10.1136/jme.2002.002782

Correspondence to: M Spriggs, Ethics Unit, Murdoch Childrens Research Institute, Royál Childrens Hospital, Flemington Road, Parkville, Victoria, 3052, Australia; Centre for the Study of Health and Society, University of Parkville, University of Melbourne, Australia; Monash University Centre for Human Bioethics,

Australia; merle.spriggs@mcri.edu.au

\section{REFERENCES}

1 Spriggs M, Savulescu J. Saviour siblings. J Med Ethics 2002;28:289.

2 Anon. "Designer baby" ruling condemned. 2002 Jul 18, BBC News http://news.bbc.co.uk/1/hi/ health/2134314.stm (accessed 7 Jul 2004).

3 Anon. Q \& A: "designer baby" refusal. 2002 Aug 2, BBC News http://news.bbc.co.uk/1/hi/ health/2167792.stm (accessed 7 Jul 2004)

4 Anon. Boy's life hangs on designer brother. The Australian. 2003 Jun 20: news section, 10

5 Anon. Ethics fears raised over "designer baby". 2002 Feb 23, BBC News http://news.bbc.co.uk/ 1/hi/health/1837197.stm (accessed 7 Jul 2004)

6 Anon. Couple fight on for genetically selected baby. 2002 Aug 2 BBC News http:// news.bbc.co.uk/1/hi/programmes/breakfast/ 2167608.stm (accessed 7 Jul 2004).

7 National Consultative Ethics Committee for Health, Life Sciences (CCNE). Reflections on an extension of preimplantation genetic diagnosis: opinion no 72, http://www.ccne ethique.fr/english/avis/a_072.htm (accessed 7 Jul 2004). 